\title{
Strategic Orientation, Corporate Innovation, and Marketing Performance (A Study of Ikat Weaving Industry in Bali)
}

\author{
Ni Nyoman Kerti Yasa ${ }^{1}$, I Putu Gde Sukaatmadja ${ }^{2}$, I G. A. Dewi Adnyani ${ }^{3}$, \\ I Wayan Mudiartha Utama ${ }^{4}$, Gede Merta Sudiartha ${ }^{5}$ \\ ${ }_{1,2,3,4,5}$ Study Program of Management, Economic and Business Faculty Udayana University
}

\begin{abstract}
This research was conducted with the background of the phenomenon of increasingly tight competition due to the enforcement of MEA in 2015. Therefore, all businesses, including Small Micro Enterprises (SMEs) of ikat weaving industrial sector should anticipate by implementing strategic orientation, corporate innovation to achieve marketing performance. The objective of this study is to explain the effect of strategic orientation to corporate innovation and marketing performance of Ikat Weaving industry in Bali. To achieve these objectives, this study took a sample of 100 people who are owners or SME managers of Ikat Weaving industry in Bali by applying the analysis of Structural Equation Modelling (SEM). The result of this study shows that Strategic Orientation (Market Orientation, System Information Orientation, and Entrepreneurship Orientation) has positive and significant effect to corporate innovation. Strategic orientation has positive and significant effect to marketing performance. And corporate innovation have positive and significant effect to marketing performance.

Implication of study contributes to SME owners/ managers of Ikat Weaving industry in Bali to continue to implement strategic orientation and corporate innovation to achieve marketing performance.
\end{abstract}

Keywords: strategic orientation, corporate innovation, and marketing performance.

\section{Introduction}

Competition in business world is getting tight in the present era so company is required to move dynamically following the development of the existing market. The demand to dynamically move is not only for large-scale enterprises but also for small and medium-scale enterprises. SMEs also constantly consider alternative strategies which can help their business to stay ahead. Any strategies to surpass their competitors continue to be done, one of them is by way innovation, both product innovation, innovation in production processes, marketing as well as innovation within the organization ( $\mathrm{Li}$ et al., 2010; Govindarajan \& Trimble, 2012; Yalabik et al.,2012; dan Krishnan, 2012). It is expected that after carrying out innovation, SMEs are able to create competitive advantage and contribute effect to continuous increase of corporate performance (Atalaya et al., 2013).

Within last two years, namely 2014 and 2015, the performance of Small Industry of Weaving Handicraft of Bali often called Endek Fabric decreased. This is demonstrated by the data that export performance seen from foreign exchange gains of Small Industrial of Endek Fabric Handicraft in 2013 reached 21.6 million dollars, but in 2014 decreased to 21.3 million dollars, as well as in 2015 was only able to reach 21.1 million dollars (Antara News Bali, 2015). This condition needs solutions. One of the solutions having been applied was to carry out various innovations, such as: product, production process, marketing innovation, and innovation within the organization.

Innovations carried out by a business are influenced by many factors, mainly affected by external and internal factors. External factors are in the form of industrial competition intensity, changes in economic conditions and government regulations. Further innovation is also affected by internal factors, such as, corporate culture, leadership, capital resources and strategic orientation owned by their managers. Strategic orientation owned by the managers can be market orientation, technology-based information systems, and entrepreneurship orientation. All the strategic orientations of the company are able to improve innovation. The higher the market orientation of a company, the higher its innovation (Ahimbisibwe et al., 2013), the higher the orientation of the enterprise information system, the more increase the corporate innovation (Govindarajan \& Trimble (2012)), as well as the more increase the entrepreneurship orientation are able to improve corporate innovation (Nayda \& Yasa, 2016).

Similar conditions also occured in small industries of Bali weaving fabric in Bali, where the marketing performance decreased in the last three years, although various innovations have been carried out. Therefore this research intends to study the effect of strategic orientation (market, SI and entrepreneurship orientation) to corporate innovation and the marketing performance of small industry of weaving fabric handicraft of Bali. 


\section{Conceptual Framework And Research Hypotheses}

The theory applied in this study is the theory of Corporate Performance (Rong et al., 2014). Rong et $a l$. , (2014) said that corporate performance including marketing, financial, and organizational performance can be achieved if the company is able to innovate. Therefore, one of the ways that can be achieved is by constantly innovating in various fields, such as, product innovation, innovation in production processes, marketing and organizational innovation.

The phenomenon on various innovations made by a company to improve corporate performance including marketing performance was also revealed in the results of research conducted by Li et al.,2010; Govindarajan \& Trimble, 2012; Yalabik et al., 2012; dan Krishnan, 2012 . Govindarajan and Trimble (2012)'s study showed the results of innovation was able to improve corporate performance. Furthermore, the capability of innovation in this study that could be carried out by a company was driven by the strategic orientation owned by its manager. The existing strategic orientation of fabrics small industry managers of Bali, among others: market, information system, and entrepreneurship orientation. Market orientation of a manager could be seen from the focus served to consumers, competitors, as well as business cross functional coordination held in their business. The orientation of informational system indicated through their business program has applied information technology, using customer database, and began learning information systems. And entrepreneurship orientation is seen from creativity that is always developed leading to a focus on innovation and courage to bear any risks.

Based on the conceptual framework indicating the structural relationship of each variable, then conceptual framework is prepared (Figure 1).

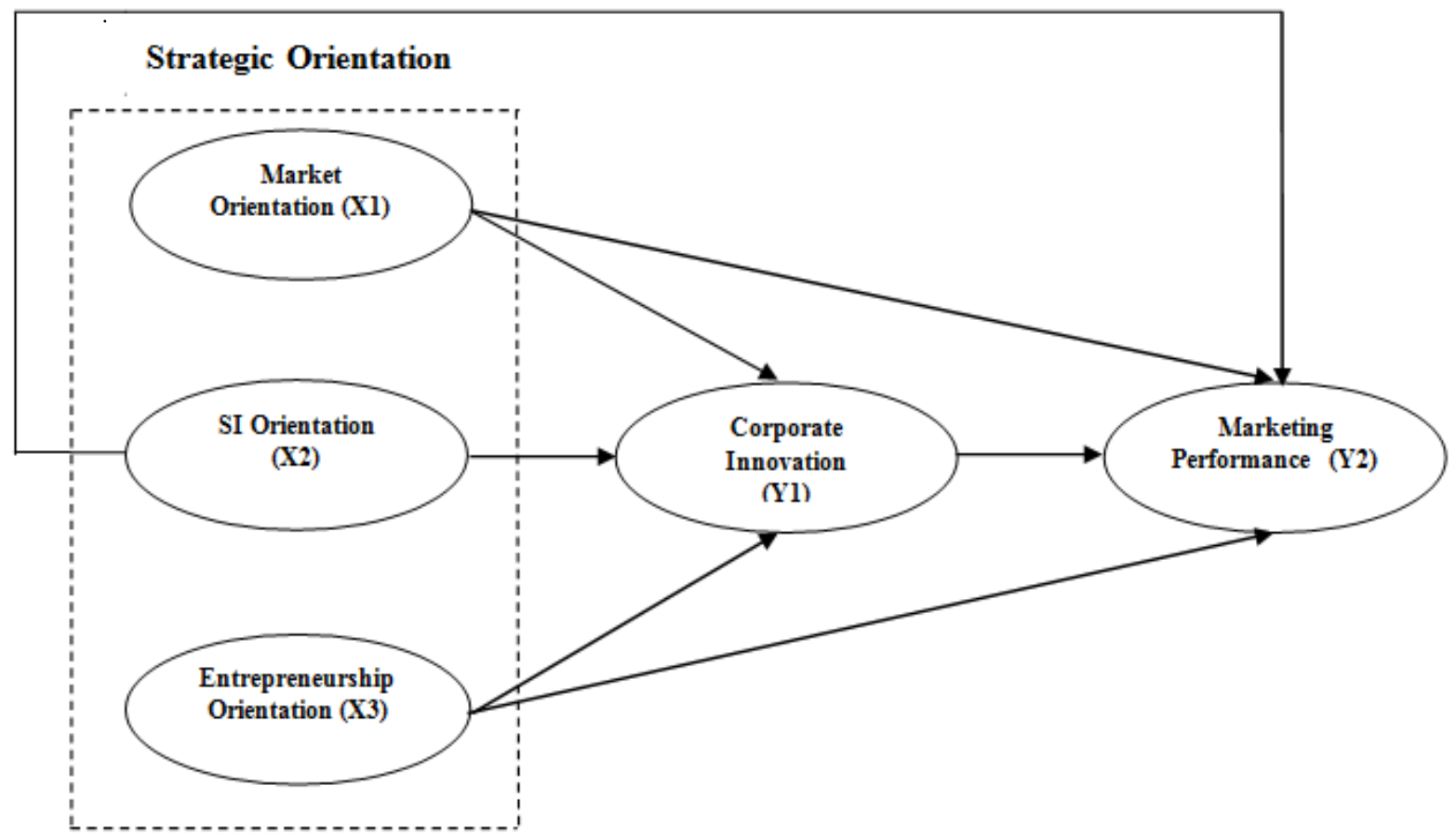

Figure 1: Conceptual Framework

Note:

$\begin{array}{lll}\text { Variable } & \text { The Name of Variabel } & \text { Resource } \\ \text { X1 } & =\text { Market Orientation } & \text { Rong } \text { et al., } 2014 \\ \text { X2 } & =\text { SI Orientation } & \text { Kadir, 2013 } \\ \text { X3 } & =\text { Entrepreneurship Orientation } & \text { Rosenbusch, 2013 } \\ \text { Y1 } & =\text { Corporate Inovation } & \text { Atalaya } \text { et al., 2013 } \\ \text { Y2 } & =\text { Marketing Performance } & \text { Parkman } \text { et al., 2012 }\end{array}$

Based on the conceptual framework, it can be described that to enhance marketing performance, the Government, Department of Cooperatives and SME, in this instance, needs considering the degree of innovation and strategic orientation, so SMEs are able to achieve improvement of marketing performance. 


\section{Research hypothesis}

This section describes a hypothetical model of testing on the effect of strategic orientation consisting of market, SI and entrepreneurship orientation through innovation which is able to achieve high marketing performance by identifying relationships as the hypothesis in this study. The relationship between strategic orientation to marketing performance is mediated by tested innovation. The selection of these variables developed previous studies by Parkman et al., 2012; Rosenbusch, 2013; Atalaya., 2013; Kadir, 2013; dan Rong et al., 2014.

$\begin{array}{lll}\text { H1 } & : \text { The increasing Market Orientation will enhance Marketing Performance. } \\ \text { H2 } & : \text { The increasing SI Orientation will enhance Marketing Performance. } \\ \text { H3 } & : \quad \text { The increasing Entrepreneurship Orientation will enhance Marketing Performance. }\end{array}$

$\mathrm{H} 4$

The increasing Market Orientation will enhance Corporate Innovation.

H5 The increasing SI Orientation will enhance Corporate Innovation.

H6 The increasing Entrepreneurship Orientation will enhance Corporate Innovation.

H7 The increasing Corporate Innovation will enhance Marketing Performance.

\section{Research Methods}

Viewed from the nature of problem, this study includes in causal research type. It meants that this study aims to examine the causal relationships between variables of strategic orientation, corporate innovation, and marketing performance. This study will be conducted in all regencies in Bali, namely, Gianyar, Klungkung, Karangasem, Buleleng, Jembrana, Tabanan, and Badung Regency as well as Denpasar City. The population of this study are all ikat weaving handicraft businesses in Bali Province. The sample size of this study are 100 SMEs of Ikat Weaving craft industries. The sample size of this study is determined by applying Slovin's formula. In such way it is expected that all samples will represent ikat weaving craft businesses in each regency/city and fianlly is able to represent entire region of Bali.

The variable indicator of strategic orientation variables (market, SI, and entrepreneurship orientation), corporate innovation and marketing performance re measured by perception of owners or managers of ikat weaving craft businesses as the strategy makers by using Likert scale of five levels, from strongly disagree $=1$, disagree $=2$, quite agree $=3$, agree $=4$, and strongly agree $=5$. The data collection technique was conducted in two ways, namely through questionnaires and interviews with the owners or managers of ikat weaving handicraft businesses, observer/academician of ikat weaving handicraft business. Basically, conducting a research is conducting measurement to the phenomen of research. The tool to measure such phenomenon is called research instruments. The indicators of this research instrument were taken from measurements that have been done by some researchers. For the measurement of market orientation variable the measurement is adopted from the measurement performed by Rong et al. (2014); for the measurement of SI orientation, it is adopted from the measurement of Kadir (2013); for the measurement of entrepreneurship orientation, it is adopted from the measurement of Rosenbusch (2013); for the measurement of corporate innovation, it is adopted from the measurement of Atalaya, et al. (2013); and for the measurement variable marketing performance, it is adopted from Parkman (2012). The form of research instrument used is a list of questions or questionnaires as the nature of this research is a survey requiring primary data. The questionnaires used were tested before the entire study with a sample size of thirty people in order to represent each region in all regencies/municipalities in Bali.

The validity and reliability of the instruments were tested in order to measure the consistency of responses given by the respondents on what you want to measure and find out. The testing of the instrument validity applied the technique of Pearson's product moment correlation with minimum limit of $\mathrm{r}=0.3$ (Sugiyono, 2014: 150). The testing of the instrument reliability is carried out by calculating the reliability coefficient of Cronbach's Alpha with a minimum limit of Alpha coefficients> 0.6 (Sekaran, 2003: 312). Both of these tests used SPSS computer program.

The causal relationships defined in this study used an unsimple model, the relationship of the variables in the model formed recursive relation. The form of this causal relationship requires an analytical tool to explain the relationship, therefore the inferential statistical methods applied in the analysis of this research is Structural Equation Modeling (SEM). 


\section{Results And Discussion}

The characteristics of respondents for this study are viewed from age, sex, education level, marital status and dependents. Age may show experience, productivity, and maturity of respondents' thought. The age of respondents of managers of Fabric Small Business in Bali varies between the youngest age of 23 years up to the oldest age of 65 years. The distribution of respondents' age of Fabric Small Business Managers in Bali are as follows: 30 years old about 10.00 percents, aged 31 to 40 years about 32.00 percents, having the age of 41 years old to 50 years about 48,00 percents, and over the age of 50 years about 10.00 percents. Of the existing distribution, the dominant one is the age of 31 to 50 years old, about 80.00 percents. The age range of 31 to 50 years old is the age that is still strong to work and suitable to be an innovative business doers because it requires effort and strong thought. The distribution of sex of SMEs managers in Bali is as follows: approximately $60.00 \%$ of the respondents are female. It shows that women are veru suitable suited with the work as managers requiring ability creativity, innovation and excellent service quality. However, it does not mean that male are not suitable to be a Fabric Small Business Managers as there are still about $40.00 \%$ of respondents are male. This amount, although less than the female respondents, the future is expected to be more and more male are becoming Ikat Weaving Handicrafts SME doers. The educational level of Fabric Small Business Managers describes knowledge, abilities, and skills in innovation. The distribution of educational level of respondents is distributed as follows. Most SME Business Operators in Bali have high school educational background, that is $65.00 \%$ of the respondents. This number describes that the quantitative level of education of SME business people in Bali has a fairly good knowledge. It can be seen that the status of the SME business doers in Ikat Weaving handicrafts sector is dominated by married status. Married status reflects the emotional stability of people that will have a positive impact on the the SME achievement performance because people having emotional stability is generally a quieter in working compared to those having no emotional stability. The number of dependents of SME businesses doers in Bali are mostly those bearing the family members of 2 to 3 persons, which is 70.00 percents.

\section{The Results of SEM Analysis}

Theoretical models on the conceptual framework of the study is said to fit if supported by empirical data. The results of SEM analysis (Appendix 6) showed that the test result of goodness of fit overall models is to determine whether the hypothetical model is supported by empirical data contained in Figure 2.

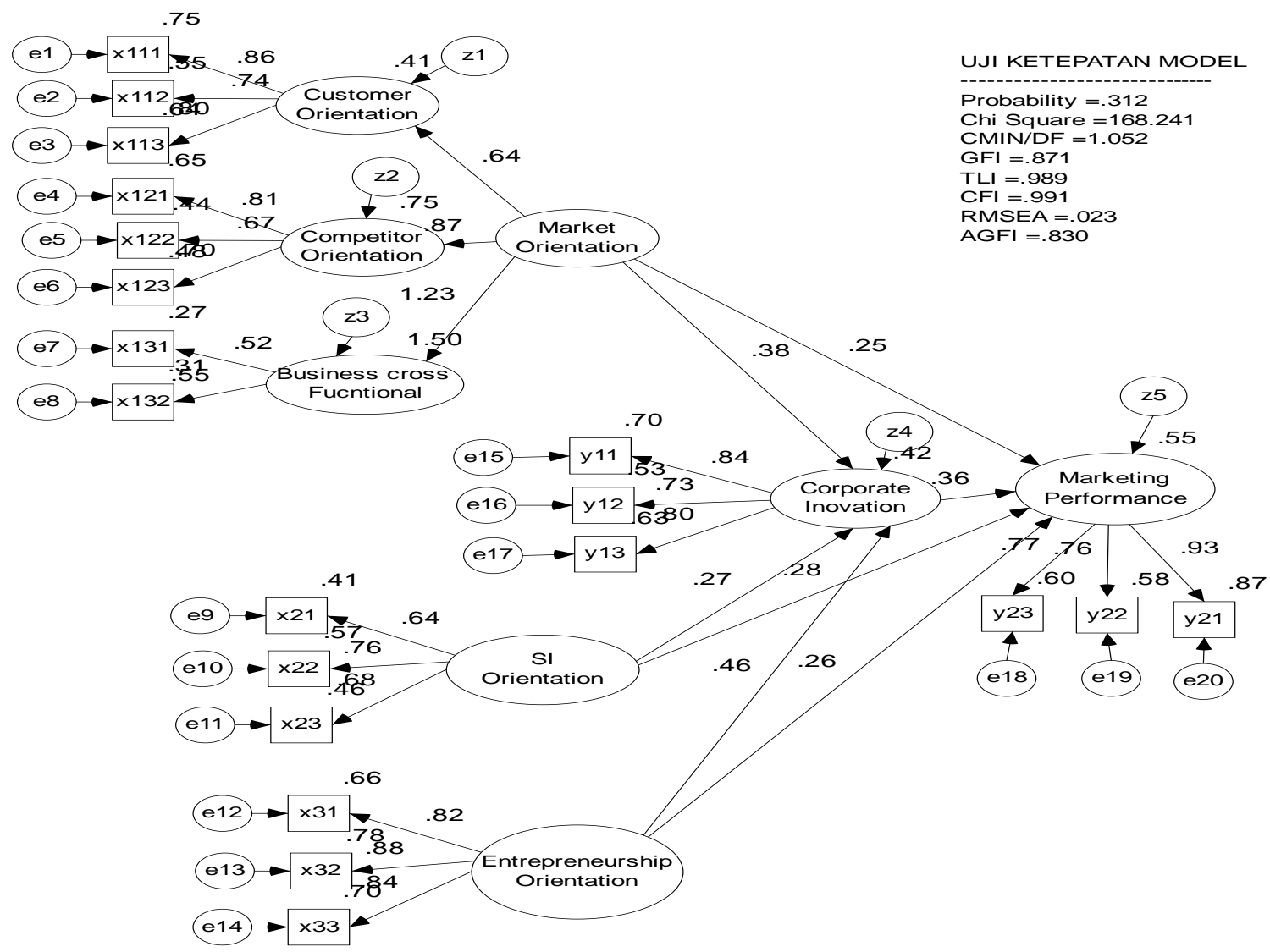

Figure 2 SEM Model 
Strategic Orientation, Corporate Innovation, and Marketing Performance (A Study of Ikat Weaving ..

Table 1: Criteria of Goodness of Overall Model

\begin{tabular}{|l|c|c|c|}
\hline \hline \multicolumn{1}{|c|}{ Criteria } & Cut-of value & Model result & Note \\
\cline { 1 - 2 } Khi Kuadrat & Small & 168,241 & \multirow{2}{*}{ Good model } \\
\hline p-value & $\geq 0,05$ & 0,312 & Good Model \\
\hline CMIN/DF & $\leq 2,00$ & 1,052 & Marginal Model \\
\hline GFI & $\geq 0,90$ & 0,871 & Marginal Model \\
\hline AGFI & $\geq 0,90$ & 0,830 & Good Model \\
\hline TLI & $\geq 0,95$ & 0,989 & Good Model \\
\hline CFI & $\geq 0,95$ & 0,991 & Good Model \\
\hline RMSEA & $\leq 0,08$ & 0,023 & \\
\hline \hline
\end{tabular}

Based on Table 1, of the eight criteria of Goodness of Fit Overall Model, six criteria state to be good model, so the model can be used.

Hypothesis testing is done by t-test ( $t$-test) on each lane of direct effect partially. Detailed results of the analysis contained in the results of SEM analysis which can be seen in Table 2 presents the results of hypothesis testing of direct effect.

Table 2 The Results of Hypothesis Testing of Direct Effect

\begin{tabular}{|l|l|c|c|c|}
\hline \hline \multicolumn{1}{|c|}{ Independent Variable } & \multicolumn{1}{c|}{ Dependent Variable } & Path Coeffisient & $\boldsymbol{p}$-value & Note \\
\hline Market Orientation (X1) & Marketing Performance (Y2) & 0,304 & 0,043 & Significant \\
\hline SI Orientation (X2) & Marketing Performance (Y2) & 0,315 & 0,016 & Significant \\
\hline Entrepreneurship Orientation(X3) & Marketing Performance (Y2) & 0,222 & 0,020 & Significant \\
\hline Market Orientation (X1) & Corporate Innovation (Y1) & 0,495 & 0,003 & Significant \\
\hline SI Orientation SI (X2) & Corporate Innovation (Y1) & 0,314 & 0,035 & Significant \\
\hline Entrepreneuship Orientation (X3) & Corporate Innovation (Y1) & 0,397 & 0,000 & Significant \\
\hline Corporate Innovation (Y1) & Marketing Performance (Y2) & 0,346 & 0,008 & Significant \\
\hline
\end{tabular}

\section{Hypothesis1 : Market Orientation (X1) has direct effect to Marketing Performance (Y2)}

The results of SEM analysis on Market Orientation variable (X1) to Marketing Performance (Y2) shows path coefficients of direct effect of 0.304 and $p$-value of 0.043 . As $p$-value $<5 \%$, then the hypothesis "Market Orientation (X1) directly affects SME Marketing Performance (Y2) is accepted. Given path coefficient has positive sign (0.304), this means that the relationship between the two variables is positive, meaning that the higher the Market Orientation (X1), the higher the Marketing Performance (Y2). Conversely, the lower the Market Orientation (X1), the lower the SMR Marketing performance of Ikat Weaving (Y2).

\section{Hypothesis2 : SI Orientation SI (X2) has direct effect to Marketing Performance (Y2)}

From the results of SEM analysis on SI Orientation variable (X1) to Corporate Performance (Y2) it was obtained path coefficients of direct effect of 0,315 and $p$-value 0,016 as p-value $<5 \%$, then the hypothesis "SI Orientation (X2) directly affects Marketing Performance (Y2)" is accepted. Given path coefficient has positive sign $(0,315)$, this means that the relationship between the two variables is positive, meaning that the higher SI Orientation (X2), the higher Marketing Performance (Y2).

\section{Hypothesis3 : Entrepreneurship Orientation (X3) has direct effect to Marketing Performance (Y2)}

From the results of SEM analysis on Entrepreneurship Orientation variable (X3) to Marketing Performance (Y2) it was obtained path coefficients of direct effect of 0,222 and p-value 0.020. As $p$-value $<5$ $\%$, then the hypothesis "Entrepreneurship Orientation (X3) directly affects Marketing Performance (Y2)" is accepted. Given path coeffiecients has positive sign $(0,222)$, this means that the relationship between the two variables is positive, this means the higher Entrepreneurship Orientation (X3), the higher Marketing Performance (Y2), conversely.

\section{Hypothesi4 : Market Orientation (X1) has direct effect to Corporate Innovation (Y1)}

From the results of SEM analysis on Market Orientation variable (X1) to UKM Corporate Innovation (Y1) it was obtained path coefficient of direct effect of 0,495 and p-value 0,003. As p-value $<5 \%$, then hypothesis "Market Orientation (X1) directly affects Corporate Innovation (Y1)" is accepted. As path coefficients has positive sign $(0,495)$, this means relation of the two variables is positive, this means the higher Market Orientation (X1), the higher Corporate Innovation (Y1), and coversely. 


\section{Hypothesis5 : SI Orientation (X2) has direct effect to Corporate Innovation (Y1)}

From the result of SEM analysis on SI Orientation variable (X2) to corporate innovation (Y1) it was obtained path coefficient of direct effect of 0,314 and p-value 0.035. As p-value < $5 \%$, then hypothesis "SI Orientation (X2) directly affects Corporate Innovetion (Y1)" is accepted. As path coefficient has positive sign $(0,314)$, this means relation of the two variables is positive, this means that the higher SI Orientation (X2), the higher corporate innovation (Y1), and conversely.

\section{Hypothesis6 : Entrepreneurship Orientation (X3) has direct effect to Corporate Innovation (Y1)}

From the result of SEM analysis on Entrepreneurship Orientation variable (X3) to UKM Corporate Innovation (Y1) it was obtained path coefficient of direct effect of 0,397 and p-value 0,000. As p-value $<5 \%$, then hypothesis " Entrepreneurship Orientation (X3) directly affects UKM Corporate Innovation (Y1)" is accepted. As path coefficient has positive sign $(0,397)$, this means relation of the two variables is positive, this means that the higher entrepreneurship orientation (X3), the higher UKM Corporate Innovation(Y1), and conversely.

\section{Hypothesis7 : Corporate Innovation (Y1) has direct effect to Marketing Performance (Y2)}

From the result of SEM analysis on Corporate Innovation variable (Y1) to UKM Marketing Performance (Y2) it was obtained path coefficient of direct effect of 0,346. and p-value 0,008.AS p-value $<5$ $\%$, then hypothesis " Corporate Innovation (Y1) directly affects UKM Marketing Performance (Y2)" is accepted. As path coefficient has positive sign $(0,346)$, this means relation of the two variables is positive, this means that the higher corporate innovation (Y1), the higher UKM marketing performance (Y2), and conversely.

\section{Discussion of Research Result}

From the calculation of validity and reliability, it can be seen that each indicator has been able to measure the variables and concepts tested as well as between one concept to the other one is independent. By doing the confirmatory factor analysis (goodness of fit test and test of factor quality significance), it is shown that the observed variables may reflect factors being analyzed. With the overall suitability test model (goodness of fit test and causal test regression weight) it has been proved that the overall models fit and causal relationship formed can be tested.

In this research, the indicator of Industrial Competition formed by the indicator of the existing competitive variables, the newcomers, their substitutes, bargaining power of suppliers, bargain power of buyers have an important role to increase the competitive advantage of Ikat Weaving industries in Bali. The results are consistent with the conditions faced by SMEs of Ikat Weaving industries in Bali. Industrial competition has led the competitive advantage of SMEs of Ikat Weaving industries in Bali is increasing.

\section{The Effect of Market Orientation to SME of Marketing Performance}

Based on Tabel 2, it can be seen that the Market Orientation variable has a significant effect to SME Marketing Performance of Ikat weaving. These results is proved by the p-value of 0.043 which is smaller than 0.05. The relationship between Market Orientatiom Variable and Marketing performance variable demonstrate positive effect characterized by inner weigh of 0,304. This result can be intepreted that the higher market orientation the higher marketing performance of Ikat weaving industry in Bali.

In this research, the indicator of market orientation formed by indicator variables of always want to fulfill market's need, follow the market, always satisfied consumers, observe the competitors, follow the trend of competitors, get the information about the competitors, all elements of the company serve consumers and all satisfy the consumers have an important role to increase marketing performance of ikat weaving industries in Bali. The results are consistent with the conditions faced by SMEs of Ikat Weaving Industries in Bali. Market Orientation has led marketing performance of SMEs of Ikat Weaving industries in Bali is increasing.

\section{The Effect of SI Orientation to the Marketing Performance}

Based on Tabel 2, it can be known that SI Orientation variable has a significant effect to marketing performance of SMEs of Ikat Weaving. These results is proved by p-value of 0,016 which is smaller than 0,05 . The relationship between SI Orientation variable and marketing performance of SMEs of Ikat Weaving demonstrate positive effect characterized by inner weight of 0,315 This result can be intepreted that the higher SI Orientation the higher marketing performance of SMEs of Ikat Weaving in Bali.

In this research indicator of SI Orientation formed by indicator variables of own SI, own SI facilities, and own SI human resources have an important role to increase marketing performance of ikat weaving industries in Bali. The research results are consistent with the condition faced by SMEs of Ikat Weaving Industries in Bali. SI Orientation has led marketing performance of SMEs of Ikat Weaving industries in Bali is increasing. 


\section{The Effect of Entrepreneurship Orientation to the Marketing Performance}

Based on Tabel 2, it can be known that Entrepreneurship Orientation variable has a significant effect to marketing performance of SMEs of Ikat Weaving. These results is proved by p-value of 0,020 which is smaller than 0,05 . The relationship between Entrepreneurship Orientation variable and marketing performance of SMEs of Ikat Weaving demonstrate positive effect characterized by inner weight of 0,222. This result can be intepreted that the higher Entrepreneurship Orientation the higher marketing performance of SMEs of Ikat Weaving in Bali. In this research, indicator of Entrepreneurship Orientation is formed by indicator variables of develop creativity, develop innovation, and risk taker have an important role to increase marketing performance of ikat weaving industries in Bali. The research results are consistent with the condition faced by SMEs of Ikat Weaving Industries in Bali. Entrepreneurship Orientation has led marketing performance of SMEs of Ikat Weaving industries in Bali is increasing.

\section{The Effect of Market Orientation to Corporate Innovation}

Based on Tabel 2, it can be known that Market Orientation variable has a significant effect to Innovation of SMEs of Ikat Weaving. These results is proved by $p$-value of 0,003 which is smaller than 0,05. The relationship between Market Orientation variable and innovation of SMEs of Ikat Weaving demonstrate positive effect characterized by inner weight of 0,495. This result can be intepreted that the higher Market Orientation the higher innovation of SMEs of Ikat Weaving in Bali.

In this research, indicator of Market Orientation is formed by indicator variables of always want to fulfill market's need, follow the market, always satisfied consumers, observe the competitors, follow the trend of competitors, get the information about the competitors, all elements of the company serve consumer and all satisfy the consumers have an important role to increase innovation of ikat weaving industries in Bali. The research results are consistent with the condition faced by SMEs of Ikat Weaving Industries in Bali. Market Orientation has led innovation of SMEs of Ikat Weaving industries in Bali is increasing.

\section{The Effect of SI Orientation to Corporate Innovation}

Based on Tabel 2, it can be known that SI Orientation variable has a significant effect to Innovation of SMEs of Ikat Weaving. These results is proved by $p$-value of 0,035 which is smaller than 0,05 . The relationship between SI Orientation variable and innovation of SMEs of Ikat Weaving demonstrate positive effect characterized by inner weight of 0,314. This result can be intepreted that the higher SI Orientation the higher innovation of SMEs of Ikat Weaving in Bali.

In this research, indicator of Market Orientation is formed by indicator own SI, own SI facilities, and own SI human resources have an important role to increase innovation of ikat weaving industries in Bali. The research results are consistent with the condition faced by SMEs of Ikat Weaving Industries in Bali. SI Orientation has led innovation of SMEs of Ikat Weaving industries in Bali is increasing.

\section{The Effect of Entrepreneurship to Corporate Innovation}

Based on Tabel 2, it can be known that Entrepreneurship Orientation variable has a significant effect to Corporate Innovation of SMEs of Ikat Weaving. These results is proved by p-value of 0,000 which is smaller than 0,05. The relationship between Entrepreneurship Orientation variable and Innovation of SMEs of Ikat Weaving demonstrate positive effect characterized by inner weight of 0,397 . This result can be intepreted that the higher Entrepreneurship Orientation the higher Innovation of SMEs of Ikat Weaving in Bali.

In this research, indicator of Entrepreneurship Orientation is formed by indicator variables of develop creativity, develop innovation, and risk taker have an important role to increase marketing performance of ikat weaving industries in Bali. The research results are consistent with the condition faced by SMEs of Ikat Weaving Industries in Bali. Entrepreneurship Orientation has led innovation of SMEs of Ikat Weaving industries in Bali is increasing.

\section{The Effect of Corporate Innovation to Marketing Performance}

Table 2 shows that Corporate Innovation has a significant effect to SME Marketing Performance. This result is supported by the p-value of 0.008 which is smaller than 0.05 . The relationship between Corporate Innovation variable and the variable of Fabric Small Business Marketing Performance showed a positive effect characterized by the existence of inner weight of 0.346 . These results can be interpreted that the higher the Corporate Innovation the higher the Marketing Performance of Fabric Small Business in Bali. In this study, the indicators Corporate Innovation formed by the variable indicator of product, process, and marketing innovation have an important role on the Marketing Performance of Fabrics Small Business in Bali. 


\section{Research implications}

As described in the analysis and discussion that this research could theoretically find relationship between the latent variables of Strategic Orientation (Market, SI, and Entrepreneurship orientation) of the Corporate Innovation and SME Marketing Performance. This research can provide conceptual contribution to many Fabrics Small Business doers. The conceptual contribution is that SMEs must constantly maintain and strengthen the corporate innovation level in a comprehensive manner through various means of innovations such as product, process, and marketing innovation so as to improve SME marketing performance.

\section{Research limitations}

This study only uses one manager or Fabrics Small Business doer as respondent in Bali so the results of this research cannot be generalized thoroughly. Mediating variables studied were Corporate Innovations variable, which turned out in this study to have a significant effect to marketing performance, so in the future it should be considered to select the other mediating variables, such as CRM and other business strategies.

\section{Conclusion}

Based on the results of research, discussion and interpretation described in the previous chapter with reference to several theories and previous research results, then it can be taken some conclusions as follows: 1) Market Orientation has positive and significant effect to Marketing Performance of Fabrics Industry, meaning that the higher the market orientation owned by the Fabrics Small Industry in Bali, the more increase the Marketing Performance; 2) Information System Orientation has positive and significant effect to Marketing performance of Ikat Weaving industry, meaning that the higher Si Orientation owned by Small Industry of Ikat Weaving in Bali, the more increase the Marketing Performance; 3) Entrepreneurship Orientation has positive and significant effect to Marketing Performance of Ikat Weaving Industry, meaning that the higher the entrepreneurship orientation owned by the Fabrics Small Industry in Bali, the more increase the Marketing Perfomance; 4) Market Orientation has positive and significant effect to Corporate innovation of Ikat Weaving Industry, meaning that the higher the market orientation owned by the Fabrics Small Industry in Bali, the more increase the Corporate Innovation; 5) SI Orientation has positive and significant effect to Corporate Innovation of Ikat Weaving industry, meaning that the higher the SI orientation owned by the Fabrics Small Industry in Bali, the more increase the Corporate Innovation; 6) Entrepreneurship Orientation has positive and significant effect to Corporate Innovation of Ikat Weaving Industry, meaning that the higher the entrepreneurship orientation owned by the Fabrics Small Industry in Bali, the more increase the Corporate Innovation; 7) Corporate Innovation has positive and significant effect to Marketing Performance, meaning that the higher the corporate innovation owned by the Fabrics Small Industry in Bali, the more increase the Marketing Performance.

\section{Literature Review}

[1]. Ahimbisibwe, G., Joseph M., Ntayi M. \& Ngoma M. (2013). Export Market Orienation,Innovation and Performance of Fruit Exporting Firm in Uganda, European Scientific Journal. Vol. 4, No. 9.

[2]. Atalaya, M., Anafarta, N., \& Sarvanc, F. (2013). The relationship between innovation and firm performance: An empirical evidence from Turkish automotive supplier industry, Procedia - Social and Behavioral Sciences. Vol. 75, pp. 226 - 235

[3]. Bakti, S., \& Harun, H. (2011). Pengaruh orientasi pasar dan nilai pelanggan terhadap kinerja pemasaran maskapai penerbangan lion air. Jurnal Manajemen Pemasaran, Vol. 3, No. 1, pp. 1-15.

[4]. Bakar, L. J. A. \& Ahmad, H. (2010). Assessing the relationship between firm resources and product innovation performance. Business Process Management Journal, Vol. 16, No. 3, pp. 420-435.

[5]. Bigliardi, B., \& Domio, A.I. (2009). An Empirical Investigation of Innovation Determinants in Food Machinery Enterprises. European Journal of Innovation Management, Vol. 12, No. 2, pp. 223-242

[6]. Fatoki, Owale. (2012). The Impact of Entrepreneurial Orientation on Access to Debt Finance and Performance of Small and Medium Enterprise in South Africa. Journal of Social and Science, Vol. 32, No. 2, pp. 121-131.

[7]. Ferdinand, A. (2002). Structural Equation Modeling Dalam Penelitian Manajemen. Fakultas Ekonomi Universitas Diponegoro, Semarang.

[8]. Felgueiraa, Teresa., \& Gouveia, Ricardo. (2012). Entrepreneurial Orientation, Market Orientation and Performance of Teachers and Researchers in Public Higher Education Institutions. Viešoji politika ir administravimas, Vol. 11, No. 4, pp. 703-718.

[9]. Foley., A. \& Fahy., J. (2004). Towards a further understanding of the development of market orientation in the firm: a conceptual framework based on the market-sensing capability. Journal of Strategic Marketing, Vol. 12, No. 4, pp. 219-230.

[10]. Govindarajan Vijay \& Trimble Chris, (2012). Reverse innovation: a global growth strategy that could pre-empt disruption at home, Strategy \& Leadership, Vol. 40, No. 5, pp. 5-11.

[11]. Hair. JR., Anderson, R.E., Thatan, R.I \& Black W.C. (1995). Multivariate Data Analysis. Fourth Edition, Prentice Hall, New Yersey.

[12]. Hoq, M., \& Norbani, H. (2009). Innovativeness: Its antecedents and impact on SME business performance. International Journal of Business and Management, Vol. 4, No. 11.

[13]. Idar, I., \& Mahmod, R. (2011). Entrepreneural and Marketing Orientation Relationship to Perspective. The SME Perspective Interdisciplinary Review of Economics and Management, Vol. 1, No. 2, pp. 1-8

[14]. Jalali, Alizera, Jaafar, Mastura \& Ramayah, Thurasamy. (2014). Entrepreneurial Orientation and Performance: The Interaction Effect of Costumer Capital. World Journal of Entrepreneurship, Management and Sustainable Develepment, Vol. 10, No. 1, pp. 4868 
[15]. Kuratko, D.F., Ireland, R.D., Covin, J.G., \& Hornsby, J.S. (2008). A model of middle-level managers' entrepreneurial behaviour. Entrepreneurship Theory and Practice, Vol. 29, No. 6, pp. 699-716.

[16]. Kraus, Sascha, Rigtering, J. P. Coen, Hughes, Mathew, \& Hosman, Vincent. (2012). Entrepreneurial Orientation and The Business Performance of SMEs: A Quantitative Study from The Netherlands. Journal Management Science, Vol. 6.

[17]. Krishnan. Rishikesha T., (2012), Innovation strategies of Indian market leaders, Journal of Indian Business Research, Vol. 4 No. 2, pp. 92-96.

[18]. Kropp, F., Lindsay., N. \& Shoham, A. (2006). Entrepreneurial, market, and learning orientations and international entrepreneurial business venture performance in South African firms. International Marketing Review, Vol. 23, No. 5, pp. $504-523$.

[19]. Li Yi, Zhou Nan, \& Si Youhe. (2010). Exploratory innovation, exploitative innovation, and performance, Nankai Business Review International, Vol. 1 No. 3, pp. 297-316.

[20]. Liu, H., Ke, Weiling., Wei, K.K., \& Hua Zhongsheng. (2013). Effects of Supply Chain Integration and Market Orientation on Firm Performance: Evidence from China.International Journal of Operations \& Production Management, Vol. 33, No. 3, pp. 322-346

[21]. Madhoushi, Mehrdad, Sadati, Abdolrahim, Delavari, Hamidreza, Mehdivand, Mohsen, \& Mihandost, Ramin. (2011). Entrepreneurial Orientation and Innovation Performance: The Mediating Role of Knowledge Management. Journal of Business Management, Vol. 3, No. 3, pp. 310-316.

[22]. Malhotra N.K. (1999). Marketing Research an Applied Oriented. Third Edition.

[23]. Marcati, A., Guido, G., \& Peluso, A. (2008). The role of SME entrepreneurs innovativeness and personality in the adoption of innovations. Research Policy, Vol. 37, No. 9, pp. 1579-1590.

[24]. Morgan, N., Slotegraaf, R. \& Vorhies, D. (2009). Linking marketing capabilities with profit Growth. International Journal of Research in Marketing, Vol. 26, No. 4, pp. 284-293.

[25]. Nayda \& Yasa Kerti, (2016), Peran Inovasi memediasi Orientasi Kewirausahaan Terhadap Kinerja Produk, E-Jurnal Manajemen Universitas Udayana, Vol. 5, No. 3, pp. 1915-1941

[26]. Parkman, Ian D., Holloway, Samuel S.,\&n Sebastio, Helder. (2012). Creative Industries: Aligning Entrepreneurial Orientation and Innovation Capacity. Journal of Research in Marketing and Entrepreneurship, Vol. 14, No. 1, pp. 95-114.

[27]. Reckhenrich, J., Kupp, M., \& Anderson, J. (2009). Understanding creativity: The manager as artist. Business Strategy Review, Vol. 20, No. 2, pp. 68-73.

[28]. Rong, F., Chang, E., Ou, C.C., \& Chou, C.H. (2014). Internal market orientation, market capabilities and learning orientation Perfect Translation\& Compunet. Taichung, Taiwan, and European Journal of Marketing, Vol. 48, No. 1, pp. 170-192

[29]. Rosenbusch, Nina, Rauch, Andreas, dan Bausch, Andreas. 2013. The Mediating Role of Entrepreneurial Orientation in The Task Environment Performance Relationship: A Meta-Analysis. Journal of Management, Vol. 39, No. 3, pp. 633-659

[30]. Sekaran, Uma. (2003). Research Methods For Business. New York: John Willey and Sons, Inc.

[31]. Sugiyono. (2014). Metode Penelitian Bisnis. Bandung: CV. Alfabeta.

[32]. Therrien, P., Doloreux, D., \& Chamberlin, T. (2011), Innovation novelty and (commercial) performance in the service sector: A Canadian firmlevel analysis. Technovation, Vol. 31, pp. 655-665.

[33]. Wang, C L., \& Ahmed, P.K. (2004). The development and validation of the organisational innovativeness construct using confirmatory factor analysis. European Journal of Innovation Management, Vol. 7, No. 4, pp. 303-313

[34]. Yalabik Baris, Howard Mickey, and Roden Sine'ad. (2012). The innovation game: lessons in strategy and managing operations, International Journal of Operations \& Production Management, Vol. 32 No. 12, pp. 1441-1459. 